\title{
A medicina na Grécia antiga
}

\section{Medicine in the ancient Grece}

\section{Denise F. Barbosa', Pedro Carlos Piantino Lemos²}

\begin{abstract}
Barbosa DF, Lemos PCP. A medicina na Grécia antiga. Rev Med (São Paulo). 2007 abr.jun.;86(2):117-9.

RESUMO: Na Grécia Antiga, até o surgimento do pensamento filosófico-médico, quase nada era conhecido sobre a anatomia interna e a fisiologia humanas. O cuidado dos doentes era feito com métodos religiosos, com o objetivo de manutenção da "energia vital", indispensável à vida. O novo pensamento passou a pregar a necessidade de se conhecer a essência natural do homem. A partir de então, textos foram escritos e, posteriormente, reunidos no "Corpus Hipocraticum", que tem como principais valores, os relacionados à ética médica.
\end{abstract}

DESCRITORES: História da Medicina. Grécia.

(a.C.)];

história da Grécia é dividida, por
historiadores modernos, em quatro
períodos: 1- Período Arcaico [séc.XIII (a.C.) - séc. V (a.C.)];

2- Período Clássico [séc. V (a.C.) - séc.IV

3- Período Helenístico-Macedônico [séc. IV (a.C.) - séc. I (a.C.)];

4- Período Helenístico-Romano [séc. I (a.C.) séc. V (d.C.)].

Os períodos mais importantes para a medicina foram o Arcaico e o Clássico.

\section{Período Arcaico}

Os gregos arcaicos quase nada conheciam sobre a anatomia interna e a fisiologia humanas. Seus conhecimentos anatômicos restringiam-se à traquéia, tida como um tubo condutor de ar para o interior do organismo; à garganta, como um órgão de entrada da bebida e do alimento; ao coração, como um órgão pulsátil; ao reto, como o segmento distal do tubo digestivo e eliminador das fezes; e à bexiga, como o reservatório de urina. Acredita-se que o conhecimento a respeito da maioria dos órgãos deu-se por observações da anatomia interna de animais que eram sacrificados.

No início desse período, os gregos, provavelmente, cuidavam dos doentes com métodos religiosos, na crença de que a doença e a saúde eram responsabilidades dos deuses. Acreditavam que o que mantinha vivo o organismo era a "energia vital", presente em todas as partes dele, e que essa era mantida por fatores absorvidos do exterior, ou seja, por alimentos, bebida e ar.

Posteriormente, eles acreditavam que os componentes do Universo (a água, a terra, o fogo e o ar) e, portanto, do próprio organismo, eram responsáveis pelas características deste, e que suas variações quantitativas representavam o "equilíbrio" e o "desequilíbrio": a saúde e a doença, respectivamente.

Porém, no século VI (a.C.), surgiu um novo pensamento (filosófico-naturalista) com o aparecimento dos filósofos-médicos, que, nos séculos seguintes, iriam criar escolas médicas e produzir os

\footnotetext{
1. Graduanda da FMUSP.

2. Doutorado e pós-graduado.

Endereço para correspondência: revistademedicina@dc.fm.usp.br
} 
textos médicos clássicos, hoje conhecidos como "Corpus Hipocraticum". Assim, os gregos arcaicos foram os introdutores do pensamento racional no âmbito das teorias médicas.

\section{Período Clássico}

Este é o período dos filósofos, historiadores, escritores, políticos e médicos gregos mais eminetes: Sócrates (470-399 a.C.), Demóstenes (384-324 a.C.), Aristóteles (384-322 a.C.), Platão (427-348 a.C.), Tucídides (455-400 a.C.), Sófocles (496-406 a.C.), Péricles (498-429 a.C.) e Hipócrates (460-377 a.C.).

Neste período, surgiu, entre os filósofos gregos, a convicção de que a natureza humana não era exclusivamente dependente dos deuses e que, por esse motivo, era fundamental o conhecimento da essência natural do homem. Assim, o pensamento médico-filosófico-naturalista, iniciado no final do Período Arcaico, foi praticado e difundido na Grécia dos séculos $\mathrm{V}$ e IV a.C. por médicos e discípulos das escolas de Cós, Cnides e Atenas.

Os conteúdos dos textos médicos originais, assim como os filosóficos, existem até hoje graças aos povos que adotaram as culturas da Grécia, mesmo após conquistá-la. Além disso, as doutrinas gregas clássicas foram acolhidas nos currículos das primeiras universidades criadas durante o domínio do Império Cristão de Carlos Magno, na Itália, na Espanha e na França, no decorrer dos séculos IX e Xd.C.

Desse modo, os conhecimentos e as doutrinas dos filósofos e dos médicos da Grécia Clássica sobreviveram até hoje, graças, principalmente, à coletânea dos textos hipocráticos da Biblioteca de Alexandria.

\section{"Corpus Hipocraticum"}

Todos os tratados que constituem, atualmente, o "Corpus Hipocraticum" (cerca de sessenta) são anônimos e, provavelmente, foram reunidos por eruditos da Escola Médica da Alexandria.

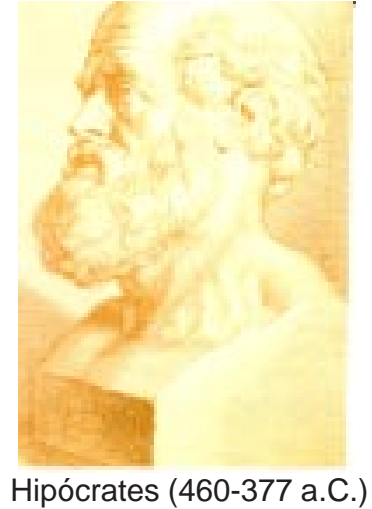

\section{A temática do tratados Hipocráticos}

O "Corpus Hipocraticum" tem seu valor pelo fato de representar o início da medicina racional, porém, seus principais valores são aqueles relacionados ao ideal ético do médico e da medicina.

Os autores hipocráticos tentavam explicar as origens das doenças atendo-se a generalidades, construindo doutrinas arbitrárias, pouco embasadas em conhecimentos da natureza física do homem e de sua anatomia interna. Imaginavam a fisiologia e a anatomia humanas análogas às das plantas e dos animais.

Os médicos gregos observavam os sinais exteriores da patologia e procuravam explicações na natureza. Eles acreditavam, por exemplo, que determinadas doenças fossem relacionadas com as condições climáticas. Assim, os gregos clássicos mantiveram as idéias dos gregos arcaicos, que acreditavam que o corpo humano era formado por constituintes básicos, os "humores", que circulavam através de vasos, entre os órgãos internos.

Se esses "humores" entrassem em desequilíbrio (devido a mudanças climáticas ou ingestão descontrolada de alimentos e bebidas) a doença era estabelecida.

\section{A anatomia nos Tratados Hipocráticos}

As descrições anatômicas são raras e aquelas que existem neles são teóricas e esquemáticas, servindo para dar suporte às suas concepções filosóficas do comportamento do sangue e dos "humores".

Há, porém, um tratado denominado "Kardia", que descreve a anatomia do coração, principalmente dos seus elementos internos. Esse tratado é totalmente diferente dos demais, pois, apesar de trechos com conceitos especulativos, como por exemplo: "a inteligência humana reside na câmara esquerda do coração", ele descreve com detalhes a anatomia cardíaca, tal como ocorre nos seguintes trechos:

"Na forma, o coração é semelhante a uma pirâmide; na cor, uma profunda cor carmim. Ele é envolto por uma membrana lisa."

"O coração é um músculo extremamente forte 'músculo' não no sentido de 'tendão', mas no sentido de uma compacta massa de carne. Ele contém em sua circunferência, duas cavidades separadas, uma aqui outra alí. Estas cavidades são bastante dissimilares: uma delas, no lado direito, repousa voltada para baixo e ajustando-se contra a outra. ... Além disto, essa câmara é muito espaçosa e muito mais cavitária do que a outra." 
"A outra cavidade repousa um pouco abaixo e se estende em direção à linha do mamilo esquerdo, a qual, de fato, está onde sua pulsação é observada."

"A superfície interior de ambas as câmaras é irregular e um tanto corroída encantadoramente."

"... você pode ver o coração pulsando em sua inteireza, enquanto as orelhas têm um movimento separado, próprio delas, como se elas inflassem e colabassem."

"Existem membranas nas cavidades, bem como fibras que se estendem, à semelhança de teias de aranha, através das câmaras do coração e que circundam os orifícios por todos os lados e implantam filamentos na parede sólida do coração."

Fragmento de "Kardia" original em grego arcaico à direita e sua tradução para o latim à esquerda.

Barbosa DF, Lemos PCP. Medicine in the ancient Grece. Rev Med (São Paulo). 2007 abr.jun.;86(2):17-9.

ABSTRACTS: In the ancient Greece, until the appearance of the philosophical and medical idea, almost nothing was known about the human's internal anatomy and physiology. The care of the ills was made using religious methods, with the goal of maintaining the "vital energy", indispensable to life. The new idea started to claim the need to know the natural essence of man. Since then, texts were written and, afterwards, assembled in the "Corpus Hipocratucum", which has as main values, the ones related to the medical ethic.

KEY WORDS: History of medicine. Greece. 